\title{
Stage I Thyroid Gland Medullary Carcinoma AJCC v8
}

National Cancer Institute

\section{Source}

National Cancer Institute. Stage I Thyroid Gland Medullary Carcinoma A/CC v8. NCI

Thesaurus. Code C141043.

Stage I includes: T1, NO, M0. T1: Tumor measuring $2 \mathrm{~cm}$ or less in greatest dimension limited to the thyroid. N0: No evidence of locoregional lymph node metastasis. M0: No distant metastasis. (from AJCC 8th Ed.) 